\title{
Edukasi Kesehatan dengan Media Video Animasi: Scoping Review
}

\author{
Siti Aisah1, Suhartini Ismail ${ }^{2 *}$, Ani Margawati ${ }^{3}$ \\ 1) Mahasiswa Doktor Ilmu Kedokteran dan Kesehatan FK UNDIP \\ 2) Keperawatan Emergensi dan Kritis Departemen Ilmu Keperawatan FK UNDIP \\ 3) Departemen Ilmu Gizi FK UNDIP \\ *) suhartini.ismail@fk.undip.ac.id
}

\begin{abstract}
Abstrak
Upaya peningkatan pengetahuan anemia pada remaja putri selama ini dilakukan melalui pemberian edukasi kesehatan. Edukasi kesehatan yang banyak digunakan saat ini masih menggunakan media yang bersifat konvensional seperti leaftlet, booklet, lembar balik, dan power point. Seiring berkembangnya zaman,media konvensional dirasa kurang efektif untuk peningkatan pengetahuan, sikap dan perilaku kesehatan. Generasi 4.0 lebih dekat dan lebih menyukai media edukasi kesehatan yang bersifat teknologi canggih seperti melalui pendekatan audiovisual dalam bentuk video animasi dengan karakter unik dan menarik. Tujuan studi ini adalah untuk mendapatkan gambaran yang komprehensif terkait edukasi kesehatan dengan menggunakan media video animasi. Studi ini dirancang dengan menggunakan metode scoping review. Pencarian artikel menggunakan databased dari Sciencedirect, Scopus, Pubmed, Springerlink dengan waktu penelitian Januari 2015 sampai Desember 2020, dengan kata kunci "video education" OR "video animation" AND " health animation" AND "animation media" AND "animation for education". Hasilnya sebanyak 11 artikel yang dilakukan analisis terdiri dari 1artikel kualitatif dan 10 artikel kuantitatif. Hasil studi ini merangkum temuan tentang video animasi sangat efektif dalam edukasi kesehatan untuk meningkatkan pengetahuan tentang kesehatan karena menarik dan artistik, mudah dimengerti, serta efektif dan informatif. Simpulan studi bahwa media video animasi terbukti signifikan dalam meningkatkan pengetahuan pasien dalam berbagai kelompok usia dan kelompok penyakit. Tenaga kesehatan penting untuk melihat peluang dari video edukasi kesehatan sebagai intervensi yang tepat dalam meningkatkan pengetahuan masyarakat tentang kesehatan pada berbagai kelompok usia.
\end{abstract}

Kata kunci : Edukasi Kesehatan, Video Animasi, Scoping Review

\section{Abstract}

Efforts to increase knowledge of anemia in adolescent girls have been carried out by providing health education. Health education that is widely used today still uses conventional media such as leaflets, booklets, flipcharts, and power points. Along with the development of the times, conventional media is deemed less effective for increasing health knowledge, attitudes and behaviors. Generation 4.0 is closer and prefers health education media that is sophisticated technology, such as through an audiovisual approach in the form of animated videos with unique and interesting characters. The purpose of this study is to obtain a comprehensive picture related to health education 
using animated video media. This study was designed using the scoping review method. Search for articles using databased from Science Direct, Scopus, Pubmed, Springerlink with the research period January 2015 to December 2020, with the keywords "video education" OR "video animation" AND "health animation" AND "animation media" AND "animation for education". The result was that 11 articles were analyzed, consisting of 1 qualitative article and 10 quantitative articles. The results of this study summarize the findings that animated videos are very effective in health education to increase knowledge about health because they are interesting and artistic, easy to understand, and effective and informative. The conclusion of the study is that animated video media is proven to be significant in increasing patient knowledge in various age groups and disease groups. It is important for health workers to see the opportunity of health education videos as an appropriate intervention in increasing public knowledge about health in various age groups.

Keywords: Health Education, Animated Videos, Scoping Review

\section{PENDAHULUAN}

Upaya peningkatan pengetahuan anemia pada remaja putri selama ini dilakukan melalui pemberian edukasi kesehatan. Edukasi atau sering disebut juga dengan pendidikan merupakan segala upaya yang dirancang untuk mempengaruhi orang lain baik individu, kelompok, atau masyarakat sehingga mereka melakukan apa yang diharapkan oleh pelaku pendidikan (Notoatmodjo, 2010), dalam hal ini pendidikan yang diberikan untuk remaja putri adalah pendidikan terkait kesehatan. Pendidikan kesehatan bertujuan meningkatkan pengetahuan dan kesadaran masyarakat untuk memelihara serta meningkatkan kesehatannya sendiri, Pendekatan yang tepat sesuai dengan tahap tumbuh kembang dengan infromasi yang sesuai kebutuhan dapat meningkatkan pengetahuan remaja putri tentang Kesehatan (Bond \& Ramos, 2019).

Di Indonesia, media pendidikan kesehatan yang banyak digunakan saat ini masih bersifat konvensional seperti dengan menggunakan leaflet, booklet, lembar balik atau power point. Media ini dipilih karena dirasa cukup murah, mudah dibuat, mudah dibawa dan menarik (Pribadi, 2014). Seiring berkembangnya zaman, beberapa penelitian menunjukkan bahwa penggunaan leaflet, power point, booklet dan lembar balik kurang efektif untuk meningkatkan pengetahuan (Li et al., 2019), permainan atau video terlebih menarik bagi generasi 4.0 yang lebih dekat dan lebih menyukai penggunaan teknologi canggih, terlebih video dengan karakter yang lucu dan unik (Szeszak et al., 2016). Penelitian menunjukkan video khususnya video animasi lebih efektif dibanding menggunakan media tradisional yang sarat akan tulisan dan membuat jenuh (Abdullah et al., 2020; Anggraeni et al., 2020). Hasil studi lain menunjukkan terdapat peningkatan pengetahuan yang signifikan pada kelompok yang diberikan pendidikan kesehatan menggunakan media video dibanding yang menggunakan simulasi (Adha et al., 2016).

Beberapa pengembangan media edukasi dengan teknologi canggih telah dilakukan, seperti melalui pendekatan audiovisual (video). Tidak hanya memiliki tampilan yang menarik, video animasi membuat informasi yang diberikan lebih bertahan lama pada daya ingat dan membuat responden puas/senang 
(Melissa Goad, Huntley-Dale, 2018). Video edukasi animasi terbukti dapat meningkatkan pengetahuan dan kepatuhan minum obat pada pasien epilepsy (Saengow et al., 2018) dan meningkatkan pengetahuan menggosok gigi pada anak-anak (10-12 tahun) (Anwar et al., 2020). Berdasarkan latar belakang inilah peneliti ingin mengetahui pengaruh pemberian Pendidikan Kesehatan menggunakan video baik animasi terhadap peningatakan pengetahuan kesehatan.

\section{METODE}

\section{Desain Studi}

Review ini menggunakan pendekatan scoping riview untuk mengidentifikasi Langkah-langkah Menyusun protocol penelitian. Desain penelitian scoping review dipilih karena sumber referensi yang peneliti gunakan bervariatif berasal dari artikel jurnal dan official websites. Scoping review merupakan metode yang digunakan untuk mengidentifikasi literatur secara mendalam dan menyeluruh yang diperoleh melalui berbagai sumber dengan berbagai metode penelitian serta memiliki keterkaitan dengan topik penelitian. Tahapan dalam Menyusun scoping review mengacu pada Arksey \& O'Malley (2005) yang telah dimodifikasi oleh Levac, Colquhoun dan O'Brien meliputi mengidentifikasi pertanyaan penelitian secara jelas dan obyektif; mengidentifikasi artikel yang relevan; pilihan literatur terkait dari artikel dan ekstrasi data; pengorganisasisan, meringkas, dan menganalisis; melaporkan hasil data (Arksey \& O'Malley, 2005). Pertanyaan penelitian ini adalah "Bagaimana Pengaruh Pendidikan Berbasis Video animasi terhadap Peningkatan Pengetahuan Kesehatan?"
Artikel yang digunakan dalam pembuatan scoping review ini metode Pendidikan Kesehatan menggunakan media video, dimana video disini mencakup video animasi. Literatur yang digunakan menggunakan bahasa Inggris. Partisipan dalam artikel yang di review yaitu remaja dan dewasa yang menjalani perawatan di RS, rawat jalan maupun kelompok resiko. Artikel dipilih berdasarkan kriteria inklusi dan ekslusi. Inklusi artikel yang digunakan: 1) Penerapan video animasi, 2) Penelitian melihat pengaruh dari intervensi terhadap pengetahuan atau respon setelah menyaksikan vidieo animasi, 3) Topik edukasi terkait kesehatan. Kriteria ekslusi artikel yaitu: 1) Intervensi video edukasi dengan kombinasi intervensi non video, 2) tidak mengukur pengetahuan secara spesifik, 3) Intervensi menggabungkan topik Kesehatan dan non kesehatan.

\section{Strategi pencarian literatur}

Pencarian literature terkait, artikel ini menggunakan data based dari Sciencedirect, Scopus dan Pubmed dengan waktu penelitian Januar 2015 hingga Desember 2020. Dalam pencarian literatur dengan menggunakan Booleon operators "OR/AND". Kata kunci yang digunakan dalam pencarian yaitu "video education" OR "video animation" AND "health animation" AND "animation media" AND "animation for education".

\section{Identifikasi dan pemilihan literatur}

Dalam melakukan scoping review ini pencarian literatur secara independen melalui databased yang sudah terpercaya. Artikel yang sudah didapatkan dilakukan analisis, perbedaan, dan duplikasi. Pada gambar 1 menjelaskan terkait proses mencari dan memilih artikel sebagai literatur dengan menggunakan Preferred Reporting Items for Systematic Reviews and Meta-analysis (PRISMA) (Moher et al., 2009).

\section{Kriteria kelayakan}




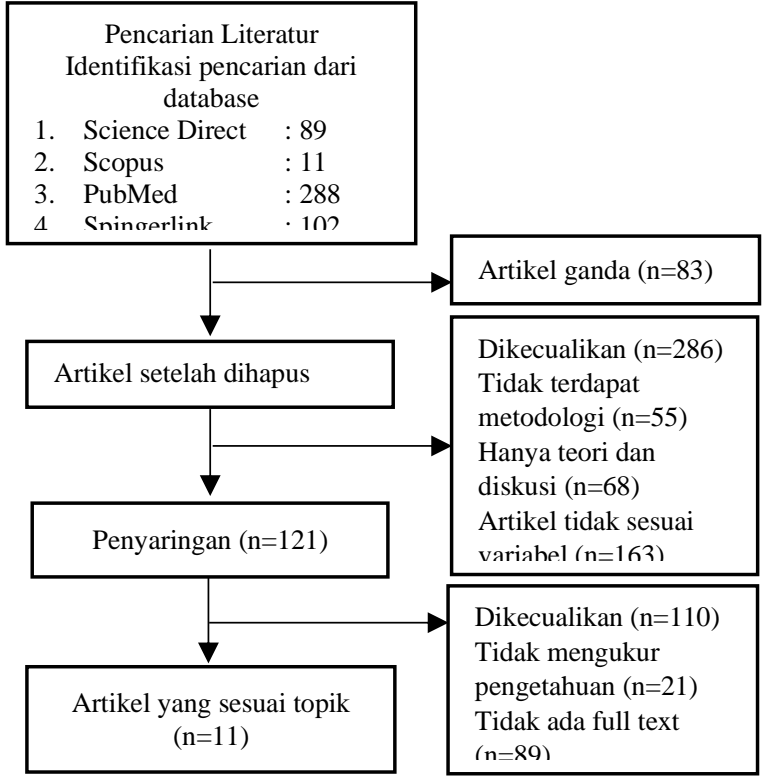

Bagan 1. PRISMA flow diagram of studies search

\section{Ekstraksi data dari literatur yang dipilih}

Artikel yang sudah didapatkan dilakukan ekstraksi data dalam bentuk matrik di Microsoft word. Domain yang digunakan dalam ekstraksi data antara lain nama peneliti, tahun, negara, judul artikel, desin, responden atau partisipan, dan hasil temuan lihat pada Tabel 1. Proses pemilihan data dilakukan melalui beberapa tahap, dimulai dari memilih artikel yang sesuai dengan tujuan penelitian yaitu video edukasi dalam meningkatkan pengetahuan remaja melalui judul artikel dan abstrak yang diperoleh dari berbagai search engine seperti google schoolar, Pubmed dan Spingerlink. Artikel yang sesuai selanjutnya dianalisis lebih mendalam dengan membaca keseluruhan isi artikel meliputi tahun publikasi, lokasi dan tahun penelitian, desain penelitian, karakteristik populasi, standar prosedur intervensi, tipe dan format intervensi, frekuensi dan durasi edukasi, pengukuran luaran hasil. Literatur yang terkumpul lalu dianalisis sesuai kriteria inklusi dan ekslusi yang telah ditentukan oleh penelit lalu dilakukan pemetaan artikel berdasarkan karakteristik.

\section{HASIL}

\section{Karakteristik studi}

Sebanyak 490 artikel yang didapatkan sebagai literatur dari Sciencedirect (89 artikel), Scopus (11 artikel), PubMed (288), SpringerLink (102 artikel). Ada 83 artikel yang sama pada data based untuk dikecualikan dan tersisa 407 artikel. Dari 407 artikel, 286 artikel dikecualikan karena 55 tidak terdapat metodologi, 68 hanya teori dan diskusi dan 163 artikel tidak berkaitan dengan topik dan bukan original artikel. Hasil penyaringan artikel didapatkan 120 dan dilakukan pengecualian terkait penjelasan dan artikel lengkap didapatkan 11 artikel terkait. Dari 11 artikel yang akan dilakukan analisis, 1 artikel dengan desain penelitian kualitatif sedangkan 10 artikel dengan desain kuantitatif. Diantara 11 artikel yang akan dilakukan analisis semuanya membahas tentang pengaruh vidio animasi terhadap pengetahuan. Populasi pada artikel yang dilakukan analisis terdiri dari pasien dan keluarga pasien.

\section{Ringkasan temuan pada literatur}

Seluruh artikel yang dianalisi didapatkan video animasi diterapkan pada berbagai kasusnya meliputi epileps, HIV, glaucoma, periodontal, reproduksi, transplantasi ginjal, disfagia dan tumbuh kembang anak. Kelompok usia yang terlibat dalam penelitian yaitu meliputi remaja-dewasa 9 artikel (90\%) dan anak 1 (10\%). (25\%) terhadap pengaruh video dengan membandingkan kelompok kontrol dan kelompok perlakuan.

Artikel ini secara umum melihat pengaruh pemberian video edukasi terhadap peningkatan pengetahuan baik 
mengenai penyakitnya maupun informasi Kesehatan secara umum. Hasil review terhadap 10 artikel didapatkan hasil video animasi dirasakan sangat efektif untuk meningkatkan pengetahuan tentang Kesehatan karena menarik, mudah dimengerti dan informatif.

\section{Tema 1: Menarik}

Literatur yang didapatkan, 6 artikel mengatakan video animasi menarik untuk dijadikan media edukasi. Adanya gambar bergerak yang lucu/unik (Cleeren et al., 2014; Govender et al., 2019; Housten et al., 2020; Kayler et al., 2019; Saengow et al., 2018), penuh warna dan bersuara sehingga menjadikan media ini tidak membuat jenuh/menghibur (Bond \& Ramos, 2019). Pendapat ini tidak hanya disampaikan oleh partisipan anak-anak ataupun remaja, kelompok usia dewasa juga mengatakan hal yang sama akan animasi. Sebagian partisipan juga mengatakan merasa terhibur dengan puas dengan menyaksikan animasi ini, sehingga proses belajar menjadi lebih menyenangkan dan waktu tidak terasa berjalan lebih cepat (Kayler et al., 2019). Gambar yang menarik ini juga membuat peserta bisa leboh fokus memperhatikan materi edukasi (Li et al., 2019; Szeszak et al., 2016).

Tema 2: Mudah dimengerti

Selain menarik, partisipan juga mengatakan komposisi gambar yang lebih banyak dibanding tulisan membuat informasi yang diberikan lebih mudah dimengerti(Housten et al., 2020; Kayler et al., 2019; Wouters et al., 2019). Gambar/ilustrasi yang ada memberikan kemudahan bagi partisipan untuk membayangkan penjelasan yang disampaikan disbanding jika semua informasi diberikan dalam bentuk tulisan(Al Owaifeer et al., 2018), khuusnya bagi pasien dengan gangguan penglihatan seperti glaucoma (Al Owaifeer et al., 2018). Adanya penjelasan berupa suara, juga membantu partisipan untuk menangkap informasi dari video ini, hal ini tidak dimiliki oleh media tradisional seperti Booklet, leaflet, lembar balik, baliho dan lainnya.

\section{Tema 3: Efektif dan Informatif}

10 dari 11 artikel mengatakan video animasi efektif untuk meningkatkan pengetahuan partisipan. Durasi video yang singkat namun memuat konten informasi yang sesuai dengan kebutuhan dan kondisi pasien (Govender et al., 2019) membuat media edukasi animasi ini dirasa efektif dan sangat infromatif (Kayler et al., 2019). Sehingga untuk memaksimalkan efektivitas dari video animasi, sebaiknya dilakukan survey kebutuhan akan informasi yang dibutuhkan oleh sasaran edukasi baik melalui kuisiner, diskusi maupun observasi. Efektifvitas video juga dapat di lihat dari lamanya informasi dapat bertahan di memory/ingatan seseorang, sehingga ketika dilakukan recall kelompok dengan media 3D lebih mampu mengingat informasi yang lebih banyak disbanding kelompok 2D (Cleeren et al., 2014) 
Tabel 1

Matrik analisis pada literatur

\begin{tabular}{|c|c|c|c|c|}
\hline & $\begin{array}{l}\text { Penulis, } \\
\text { tahun }\end{array}$ & Judul & $\begin{array}{c}\text { Desain dan } \\
\text { partisipan } \\
\text { penelitian }\end{array}$ & Hasil \\
\hline \multicolumn{5}{|c|}{ Vidio Animasi } \\
\hline 1 & $\begin{array}{l}\text { Tirza } \\
\text { Wouters et } \\
\text { all } \\
2019\end{array}$ & $\begin{array}{l}\text { The effect of an } \\
\text { animation video on } \\
\text { consultation time, } \\
\text { anxiety and }\end{array}$ & $\begin{array}{l}\text { Kohort } \begin{array}{l}\text { dengan } \\
\text { metode pre-post } \\
\text { dengan control. }\end{array} \\
122 \quad \text { partisipan } \\
\text { dengan colposcopy. }\end{array}$ & $\begin{array}{l}\text { Terdapat perbedaan waktu konsultasi } \\
\text { yang signifkkan pada kelompok } \\
\text { intervensi dengan median } 140 \text { detik } \\
\text { dibanding kelompok kontrol dengan } \\
\text { median } 269 \text { detik. Penjelasan } \\
\text { prosedur Tindakan yang diberikan } \\
\text { melalui video dapat dipahami } \\
\text { sehingga dokter tidak perlu } \\
\text { mengiformasikan kembali. }\end{array}$ \\
\hline 2 & $\begin{array}{l}\text { Keosha T } \\
\text { Bond } \\
2019\end{array}$ & $\begin{array}{l}\text { Utilization of an } \\
\text { Animated Electronic } \\
\text { Health Video to } \\
\text { Increase Knowledge of } \\
\text { Post-and Pre-Exposure } \\
\text { Prophylaxis for HIV } \\
\text { Among African } \\
\text { American Women: } \\
\text { Nationwide Cross- } \\
\text { Sectional Survey }\end{array}$ & $\begin{array}{l}\text { A cross-sectional } \\
116 \text { partisipan } \\
\text { wanita Afrika } \\
\text { dengan HIV. }\end{array}$ & $\begin{array}{l}\text { 89\% partisipan menilai video animasi } \\
\text { baik dan sangat baik. Video animasi } \\
\text { memiliki nilai yang tinggi untuk } \\
\text { meningkatkan pengetahuan tentang } \\
\text { larangan penggunaan alholol dan obat } \\
\text { terlarang ( } \mathrm{P}=0.004) \text {, larangan } \\
\text { melakukan sex tanpa pelindung } \\
(\mathrm{P}=0.03) \text {, and larangan kekerasan } \\
\text { seksual mulai usia } 18(\mathrm{P}=0.004) . \\
\text { Vidio animasi direkomendasikan } \\
\text { sebagai media untuk meningkatkan } \\
\text { pengetahuan dan kesadaran tentang } \\
\text { HIV karena memiliki kelebihan } \\
\text { mendidik, menghibur, dan cocok } \\
\text { untuk wanita. }\end{array}$ \\
\hline 3 & $\begin{array}{l}\text { Adi } \\
\text { Mohammed } \\
\text { Al } \\
\text { Owaifeer, } \\
2018\end{array}$ & $\begin{array}{l}\text { The effect of a short } \\
\text { animated educational } \\
\text { video on knowledge } \\
\text { among glaucoma } \\
\text { patients }\end{array}$ & $\begin{array}{l}\text { Pre-post } \\
\text { intervention study. } \\
196 \quad \text { partisipan } \\
\text { pasien glaucoma. }\end{array}$ & $\begin{array}{l}\text { Video animasi efektif dalam jangka } \\
\text { pendek untuk meningkatkan } \\
\text { pengetahuan pada pasien glaucoma. } \\
\text { Metode ini dapat digunakan sebagai } \\
\text { alternatif metode edukasi tradisional } \\
\text { karena memudahkan pasien untuk } \\
\text { memahami informasi disbanding } \\
\text { membaca booklet, leaflet atau media } \\
\text { cetak lainnya. }\end{array}$ \\
\hline 4 & $\begin{array}{l}\text { Ashley J } \\
\text { Housten } \\
2020\end{array}$ & $\begin{array}{l}\text { Does Animation } \\
\text { Improve } \\
\text { Comprehension of Risk } \\
\text { Information in Patients } \\
\text { with Low Health } \\
\text { Literacy? } \\
\text { Randomized Trial }\end{array}$ & $\begin{array}{l}\text { Randomized } \\
\text { controlled trial } \\
\text { (RCT). } \\
\begin{array}{l}187 \quad \text { partisipan } \\
\text { pasien }\end{array}\end{array}$ & $\begin{array}{l}\text { Perbandingan rata-rata pengetahuan } \\
\text { (standar deviasi) pada kelompok } \\
\text { media audiobooklet dengan } 66.8 \\
(16.4) \text {, video animasi } 65.0(18.6) \text { dan } \\
\text { video statis } 62.0(20.4) \text {. } \\
\text { Media gambar memudahkan pasien } \\
\text { memahami informasi, konten menarik,, } \\
\text { Tidak ada perbedaan signifikan pada } \\
\text { pengetahuan kelompok yang } \\
\text { menggunakan media audiobooklet, } \\
\text { video animasi dan video statis. }\end{array}$ \\
\hline
\end{tabular}




\begin{tabular}{|c|c|c|c|c|}
\hline 5 & $\begin{array}{l}\text { Gertjan } \\
\text { Clreeren } \\
2015\end{array}$ & $\begin{array}{l}\text { Role of } 3 D \text { animation in } \\
\text { periodontal patient } \\
\text { education: } \\
\text { randomized } \\
\text { trial }\end{array}$ & $\begin{array}{l}\text { Randomized } \\
\text { controlled trial } \\
\text { (RCT). } \\
68 \text { partisipan pasien } \\
\text { periodontal. }\end{array}$ & $\begin{array}{l}\text { Pasien yang menerima intervensi } \\
\text { video animasi 3D memiliki skor } \\
\text { pengetahuan yang lebih tinggi baik } \\
\text { pada fase post-test maupun pada fase } \\
\text { follow-up test, dibanding pada } \\
\text { kelompok yang menerima intervensi } \\
\text { menggunakan animasi 2D (sketsa). } \\
\text { Animasi 3D lebih efektif disbanding } \\
\text { gambar nyata bagi pasien periodontal } \\
\text { untuk meningkatkan recall } \\
\text { pengetahuan. 3D animasi merupakan } \\
\text { media yang lebih kuat untuk } \\
\text { mendapmpingi proses penyampaian } \\
\text { informasi. }\end{array}$ \\
\hline 6 & $\begin{array}{l}\text { Szofia } \\
\text { Szeszak } \\
2016\end{array}$ & $\begin{array}{l}\text { Animated educational } \\
\text { video to prepare } \\
\text { children for MRI } \\
\text { without sedation: } \\
\text { evaluation of the } \\
\text { appeal and value }\end{array}$ & $\begin{array}{l}\text { pre- and post- } \\
\text { viewing } \\
\text { questionnaires and } \\
\text { structured } \\
\text { interviews }\end{array}$ & $\begin{array}{l}\text { Terjadi peningkatan skor pengetahuan } \\
\text { secara signifikan anak-anak pada } 3 \text { dari } \\
7 \text { pertanyaan. } \\
96 \% \text { mengatakan menyukai video } \\
\text { animasi MRI } \\
\text { 87\% mengatakan ingin melihat video } \\
\text { animasi tentang prosedur lainnya yang } \\
\text { ada di RS. } \\
\text { Anak-anak mengatakan animasi yang } \\
\text { ada di video tampak ramah dan } \\
\text { bersahabat (100\%), menyukai animasi } \\
\text { MRI (100\%), melakukan prosedur MRI } \\
\text { dengan senang setelah menonton } \\
\text { animasi (95,7\%), takut menjalani } \\
\text { prosedur MRI (73,9\%), bisa memberi } \\
\text { informasi tentang MRI ke teman } \\
\text { (73,9\%). } \\
\text { Video animasi dapat menarik } \\
\text { perhatian anak secara baik, sehingga } \\
\text { anak lebih fokus dan memperhatikan } \\
\text { informasi yang diberikan. }\end{array}$ \\
\hline 7 & $\begin{array}{l}\text { Vitchayapo } \\
\text { rn } \\
\text { Emarach } \\
\text { Saengow } \\
2018\end{array}$ & $\begin{array}{l}\text { Epilepsy video } \\
\text { animation: Impact on } \\
\text { knowledge and drug } \\
\text { adherence in pediatric } \\
\text { epilepsy patients and } \\
\text { caregivers }\end{array}$ & $\begin{array}{l}\text { Randomized } \\
\text { controlled Trial } \\
\text { (RCT). } \\
\text { 214 partisipan anak } \\
\text { dengan 647ebagian. }\end{array}$ & 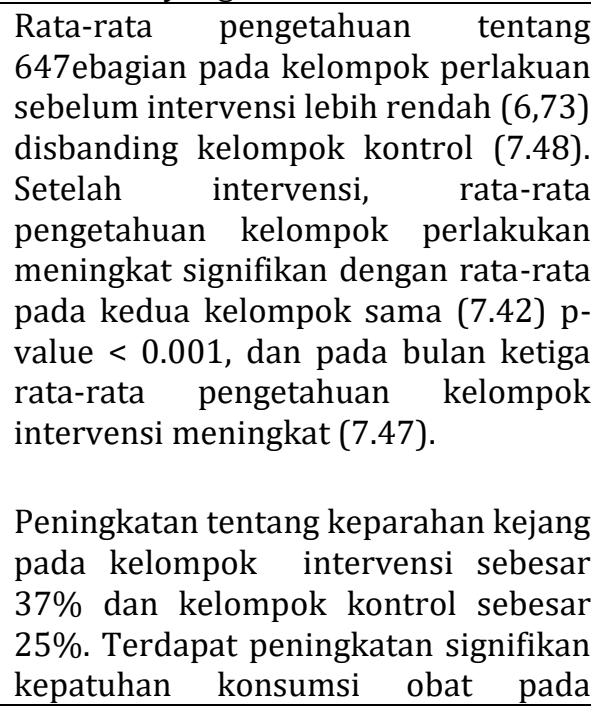 \\
\hline
\end{tabular}




\begin{tabular}{|c|c|c|c|c|}
\hline & & & & $\begin{array}{l}\text { kelompok intervensi } 648 \text { ebagian } 648 \mathrm{~g} \\
\text { kelompok kontrol. Video animasi } \\
\text { menjadi metode baru yang menarik, } \\
\text { informatif, mudah di mengerti, dalam } \\
\text { memberikan edukasi pada pasien } \\
\text { maupun petugas Kesehatan untuk } \\
\text { meningktakan pengetahuan, } \\
\text { kepatuhan konsumsi obat dan } \\
\text { kewaspadaan terhadap kejang. }\end{array}$ \\
\hline 8 & $\begin{array}{l}\text { I Wayan } \\
\text { Romantika } \\
\text { et all } \\
2020\end{array}$ & 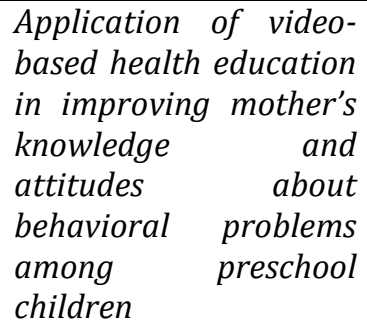 & $\begin{array}{l}\text { Quasi-experimental } \\
\text { dengan desain pret- } \\
\text { post test control } \\
\text { group } \\
122 \text { partisipan ibu } \\
\text { dengan anak usia } \\
\text { pre-school. }\end{array}$ & $\begin{array}{l}\text { Terdapat perbedaan pengetahuan } \\
(\mathrm{p}=0.004) \text { dan perilaku }(\mathrm{p}=0.04) \text { yang } \\
\text { signifikan pada kelompok intervensi } \\
\text { disbanding kelompok kontrol. Media } \\
\text { video dirasakan lebih menarik dan } \\
\text { memudahkan ibu dalam memahami } \\
\text { informasi yang diberikan. }\end{array}$ \\
\hline 9 & $\begin{array}{l}\text { Roganie } \\
\text { Govender } \\
\text { et all } \\
2019\end{array}$ & $\begin{array}{l}\text { Helping Patients With } \\
\text { Head and Neck Cancer } \\
\text { Understand Dysphagia: } \\
\text { Exploring the Use of } \\
\text { Video-Animation }\end{array}$ & $\begin{array}{l}\text { Kualitatif dengan } \\
\text { metode } \\
\text { fenomenologi } \\
13 \quad \text { Partisipan } \\
\text { dengan Disfagia. }\end{array}$ & $\begin{array}{l}\text { Hasil wawancara didapatkan } 4 \text { tema: } \\
\text { ketertarikan dan keterikatan dengan } \\
\text { pasien, tingkat penerimaan gambar } \\
\text { dan narasi, informasi persyaratan dan } \\
\text { pembelajaran, keterikatan personal } \\
\text { dan 648ebagian langsung. Kesimpulan } \\
\text { setelah melihat video animasi, } \\
\text { partisipan mengatakan video dapat } \\
\text { diterima, menarik, informatif, dan } \\
\text { relevan dengan sebagian besar kondisi } \\
\text { pasien. }\end{array}$ \\
\hline 10 & $\begin{array}{l}\text { Liise K } \\
\text { Kayler et all } \\
2019\end{array}$ & $\begin{array}{l}\text { Development and } \\
\text { preliminary evaluation } \\
\text { of ilearn KAS: An } \\
\text { animated video about } \\
\text { kidney allocation to } \\
\text { support transplant } \\
\text { decision-making }\end{array}$ & $\begin{array}{l}\text { Quasi-experimental } \\
\text { dengan desain one- } \\
\text { group, pre-post test } \\
50 \quad \text { partisipan } \\
\text { dengan gagal ginjal. }\end{array}$ & $\begin{array}{l}\text { Lebih dari } 87 \% \text { partisipan } \\
\text { memberikan penilaian yang baik } \\
\text { terhadap video animasi. Terdapat } \\
\text { peningkatan pengetahuan tentang } \\
\text { transplantasi sebelum dan sesudah } \\
\text { intervensi (78\% vs } 94 \%, \mathrm{P}=0.008) \text {, } \\
\text { ketepatan pengambilan keputusan } \\
\text { mandiri (64\% vs } 88 \%, \mathrm{P}<0.001) \text { and } \\
\text { keyakinan akan kewajaran }(76 \% \text { vs } \\
90 \%, \mathrm{P}=0.02) \text {. } \\
\text { Video aninasi mudah di mengerti } \\
(96 \%), \text { menarik (96\%), informatif } \\
(88 \%) \text {, sesuai untuk masa depan } \\
(94 \%), \text { nyaman }(94 \%), \text { dan menghibur } \\
(98 \%) \text {. }\end{array}$ \\
\hline 11 & $\begin{array}{l}\text { Jina Li } \\
2019\end{array}$ & $\begin{array}{l}\text { Impact of an Animation } \\
\text { Education Program on } \\
\text { Promoting Compliance } \\
\text { With Active Respiratory } \\
\text { Rehabilitation in } \\
\text { Postsurgical Lung } \\
\text { Cancer Patients }\end{array}$ & $\begin{array}{l}\text { a single-institution, } \\
\text { 2-group, } \\
\text { randomized, } \\
\text { controlled, }\end{array}$ & $\begin{array}{l}\text { Terdapat peningkatan rata-rata nilai } \\
\text { pengetahuan sebelum } 59,5 \text { menjadi } \\
73,3 \text { pada hari ke tiga dan } 79,8 \text { saat } \\
\text { keluar dari RS.penggunaan video } \\
\text { animasi lebih efektif disbanding } \\
\text { penggunaan powerpoint, poster, video, } \\
\text { materi dari internet atau edukasi face } \\
\text { to face. } \\
\text { Video animasi memiliki karakter yang } \\
\text { hidup dan menarik, menarik perhatian, } \\
\text { membantu peserta untuk } \\
\text { mendemonstrasikan, adanya skenario } \\
\text { dan cerita. }\end{array}$ \\
\hline
\end{tabular}




\section{PEMBAHASAN}

Keberhasilan sebuah edukasi dipengaruhi beberapa factor seperti pendidikan, lama waktu paparan, jenis kelamin, sumber informasi/media edukasi, Pendidikan, stress psikologis, budaya dan efikasi diri dan dukungan sosial (Hardan-Khalil, 2020; Oh, 2020). Media pendidikan kesehatan berperan penting dalam membantu audien memahami dan menangkap informasi yang terkandung. Disebut media pendidikan karena alat-alat tersebut merupakan alat saluran untuk menyampaikan informasi tentang kesehatan, karena alat-alat tersebut digunakan untuk mempermudah penerimaan pesan-pesan kesehatan untuk masyarakat. Alat bantu peraga atau media edukasi dapat dibagi menjadi sebelas macam sesuai dengan tingkat intensitas tiap-tip media tersebut dalam suatu kerucut. Pada kerucut tersebut benda asli memiliki intensitas paling tinggi, kemudian audio visual berada pada urutan ketiga sampai kelima sedangkan kata-kata atau tulisan intensitasnya paling rendah bila digunakan sebagai media edukasi(Muhson, 2010; Notoadmojo, 2011; Sari, 2019). Beberapa penelitian efektifitas video terhadap pengetahuan telah dilakukan dan menunjukkan adanya peningkatan yang signifikan terkait pengetahuan setelah diberi edukasi melalui video (Herron et al., 2019).(Wischer et al., 2018).

Beberapa penelitian telah dilakukan untuk melihat media yang efektif dalam meningkatkan pengetahuan, sikap dan perilaku masyarakat. Media yang cukup sering digunakan tenaga kesehatan dalam penyuluhan atau edukasi adalah leaflet, namun jika dibanding media lain seperti video kurang efektif (Beaujean et al., 2016; Cynthia Ayu Ramadhanti, Dea Amarilisa Adespin, 2019; Nindya Kurniawati, 2012). Selain meningkatkan pengetahuan (Alyssa Weakley, Joyce W Tam , Catherine Van
Son, 2019; Daniel Hogan, Tina DiMartino , Jianfang Liu , Kari A Mastro, Elaine Larson, 2018; Mary Carter Denny, Farhaan Vahidy , Kim Y T Vu, Anjail Z Sharrief, 2017), video juga mampu merubah sikap (Hui Zhang, Evalotte Mörelius, Sam Hong Li Goh, 2019), performa (Hui Zhang, Evalotte Mörelius, Sam Hong Li Goh, 2019), perilaku (Nicola Rosaasen, Rahul Mainra, Azaad Kukha-Bryson, Victoria Nhin , Paraag Trivedi , Ahmed Shoker, Jay Wilson , Raj Padmanabh, 2018), kebiasaan, kepercayaan diri (Alyssa Weakley, Joyce W Tam , Catherine Van Son, 2019; Sanjai Sinha, John Dillon, Savira Kochhar Dargar , Alexi Archambault, Paul Martin , Brittney A Frankel , Jennifer Inhae Lee, Amanda S Carmel \& Expand, 2019) hingga kualitas hidup (Ming-Huei Lee, Huei-Ching Wu , Chien-Ming Tseng, Tsung-Liang Ko , TangJun Weng, 2018) individu. Video edukasi efektif sebagai media edukasi, mendorong dan menguatkan kesadaran diri seseorang untuk melaporkan perubahan perilaku.

Video edukasi terbukti dapat digunakan sebagai sarana promosi dan edukasi yang komprehensif untuk meningkatkan pengetahuan, sikap dan perilaku kesehatan.(Ann L Kellams, Kelly K Gurka , Paige P Hornsby , Emily Drake, 2018) Efektivitas penggunaan media video harus memperhatikan 3 hal berikut yaitu bagaimana memanajemen kemampuan kognitif dalam menerima pesan dari video, bagaimana memaksimalkan keterikatan/keterlibatan paserta didik terhadap video dan bagaimana cara mengupayakan pembelajaran aktif (active learning) dari peserta didik(Brame, 2016).

Pendekatan metode edukasi lainnya dikembangkan dengan menggunakan media sosial "Facebook" dimana hasilnya menunjukkan media ini berkontribusi dalam pendidikan kesehatan reproduksi yang interaktif, menyenangkan, praktis/sederhana, mengurangi rasa malu remaja untuk berdiskusi terkait topik reproduksi, mendekatkan remaja dengan 
layanan kesehatan melalui peningkatkan kesekatan remaja dan tenaga kesehatan(Joyce Mazza Nunes Aragão 1, Fabiane do Amaral Gubert 2, Raimundo Augusto Martins Torres 2, Andréa Soares Rocha da Silva 3, 2018). Sosial media sangat bermanfaat dalam memberikan edukasi dan membantu remaja dalam meningkatkan kesehatan mentalnya(Michelle O'Reilly, Nisha Dogra, Jason Hughes, Paul Reilly, Riya George, 2019).

Bentuk tampilan pada metode media yang diminati remaja adalah menariknya bentuk gambar dan video, sehingga informasi yang disampaikan lebih mudah dipahami. Media berupa video dirasakan lebih mudah diakses, efektif dan efisien(Nicola Rosaasen, Rahul Mainra, Azaad Kukha-Bryson, Victoria Nhin , Paraag Trivedi , Ahmed Shoker, Jay Wilson , Raj Padmanabh, 2018), sehingga banyak dimanfaatkan sebagai sarana promosi dan edukasi Kesehatan. Beberapa penelitian telah menunjukkan perbedaan yang signifikan antara penggunaan media tulisan (booklet, leaflet, koran), suara/audio (radio), visual/gambar (poster, baliho) dan audio visual (video) dimana didapatkan metode gabungan audio visual menunjukkan hasil yang lebih signifikan untuk meningkatkan pengetahuan dan informasi yang didapatkan lebih bertahan lama (daya ingat)(Melissa Goad, Huntley-Dale, 2018). Tidak hanya memiliki tampilan yang menarik, video edukasi membuat informasi yang diberikan lebih bertahan lama dan responden puas/senang.(Melissa Goad, Huntley-Dale, 2018) Selain pengetahuan, audio visual juga dapat merubah perilaku kesehatan seseorang(Arneliwati \& , Agrina, 2018). Penggunaan audiovisual secara signifikan meningkatkan perubahan perilaku dan tindakan keluarga terkait pencegahan DHF (Arneliwati \&, Agrina, 2018)

Pengembangan lainnya dilakukan pada tampilan video, yaitu menggunakan pendekatan animasi. Video edukasi animasi terbukti dapat meningkatkan pengetahuan dan kepatuhan minum obat pada pasien epilepsy dan meningkatkan pengetahuan menggosok gigi pada anakanak (Saengow et al., 2018; Szeszak et al., 2016). Video animasi didapati lebih menarik karena memiliki karakter yang lucu, penuh warna dan terlihat ramah hal ini membuat audiens merasa dekat dan nyaman Ketika mendengarkan informasi yang diberikan. Selain itu, gambar yang sarat akan warna kemudian bergerak sangat sesuai bagi kelompok anak-anak, remaja maupun dewasa dengan jenis kelamin perempuan (Bond \& Ramos, 2019; Cleeren et al., 2014). Untuk meningkatkan efektivitas dari video animasi ini, maka konten informasi, skenario dan karakter tokonya harus sesuai dengan kebutuhan dan keinginan dari audien (Govender et al., 2019) agar daya tangkap dan daya lekang ingatan dari informasi ini lebih bertahan lama (Cleeren et al., 2014). Audien yang memahami dengan baik informasi yang diberikan, dapat membantu petugas Kesehatan untuk menginformasikan pada teman atau pasien lain yang mengalami kondisi serupa(Li et al., 2019).

Walaupun video animasi efektif dalam meningkatkan pengetahuan, perilaku hingga sikap namun beberapa penelitian mengatakan bahwa untuk meningkatkan retensi ilmu, kesiapsiagaan dan penyelasaian segera perlu di lengkapi dengan metode demonstrasi.(Stephanie N Pilieci, Saad Y Salim, Daithi S Heffernan, Kamal M F Itani, 2018).

\section{KESIMPULAN}

Media video telah banyak digunakan dalam proses pembelajaran salah satunya dalam edukasi Kesehatan. Penggunaan video baik animasi dalam pemberian edukasi terbukti signifikan meningkatkan pengetahuan pasien pada berbagai kelompok usia dan kelompok penyakit. 
Penggunaan video animasi ini disukai bukan karena hanya menarik dari segi tampilan tetapi juga memiliki suara yang menarik sehingga responden merasa lebih mudah memahami informasi yang diberikan dan merasa senang selama proses transfer ilmu. Selain itu, video animasi yang diberikan pada jangka waktu tertentu dapat merubah sikap, perilaku hingga kebiasaan hidup sehat. Sebagai tenaga kesehatan, penting untuk dapat melihat peluang dari video edukasi kesehatan sebagai intervensi yang tepat dalam meningkatkan pengetahuan masyarakat tentang kesehatan pada berbagai kelompok usia.

\section{DAFTAR PUSTAKA}

Abdullah, A., Firmansyah, A., Rohman, A. A., \& Etc. (2020). Health Education; The Comparison Between With Leaflet and Video Using Local Language In Improving Teenager's Knowledge of Adverse Health Effect of Smoking. Falatehah Health Journal, 7(1).

https://doi.org/https://doi.org/10.3 3746/fhj.v7i1.50

Adha, A. Y., Wulandari, D. R., \& Himawan, A. B. (2016). PERBEDAAN EFEKTIVITAS PEMBERIAN PENYULUHAN DENGAN VIDEO DAN SIMULASI TERHADAP TINGKAT PENGETAHUAN PENCEGAHAN TB PARU (Studi kasus di MA Husnul Khatimah Kelurahan Rowosari Kecamatan Tembalang Kota Semarang). JURNAL KEDOKTERAN DIPONEGORO, 5(4).

Al Owaifeer, A. M., Alrefaie, S. M., Alsawah, Z. M., Al Taisan, A. A., Mousa, A., \& Ahmad, S. I. (2018). The effect of a short animated educational video on knowledge among glaucoma patients. Clinical Ophthalmology, 12, 805-810. https://doi.org/10.2147/OPTH.S160
684

Alyssa Weakley, Joyce W Tam , Catherine Van Son, M. S.-E. (2019). Effectiveness of a video-based aging services technology education program for health care professionals. Gerontol Geriatr Educ, 40(3), 339-356. https://doi.org/doi: 10.1080/02701960.2017.1281805.

Anggraeni, Y., Tresno, N. R. I. A., Susanti, I. H., \& Mangkunegara, I. S. (2020). No TitleThe Effectiveness of Health Education Using Leaflet and Video on Students' Knowledge About the Dangers of Smoking in Vocational High School 2 Purwokerto. In Proceedings of the 1st International Conference on Community Health (ICCH 2019). atlantis-press.com. https://doi.org/https://doi.org/10.2 991/ahsr.k.200204.076

Ann L Kellams, Kelly K Gurka, Paige P Hornsby , Emily Drake, M. R. C. (2018). A Randomized Trial of Prenatal Video Education to Improve Breastfeeding Among Low-Income Women. Breastfeed Med, 13(10), 666673. https://doi.org/doi: $10.1089 / \mathrm{bfm} .2018 .0115$

Anwar, A. I., Zulkifli, A., Syafar, M., \& Jafar, N. (2020). Effectiveness of counseling with cartoon animation audio-visual methods in increasing tooth brushing knowledge children ages 10-12 years. Enfermería Clínica, 30, 285288.

https://doi.org/https://doi.org/10.1 016/j.enfcli.2019.07.104

Arksey, H., \& O’Malley, L. (2005). Scoping studies: Towards a methodological framework. International Journal of Social Research Methodology: Theory and Practice, 8(1), 19-32. https://doi.org/10.1080/136455703 


\section{6}

Arneliwati, \& , Agrina, A. P. D. (2018). The effectiveness of health education using audiovisual media on increasing family behavior in preventing dengue hemorrhagic fever (DHF). Riau International Nursing Conference, 30-33.

Beaujean, D. J. M. A., Gassner, F., Wong, A., Steenbergen, J. E., Crutzen, R., \& Ruwaard, D. (2016). Education on tick bite and Lyme borreliosis prevention, aimed at schoolchildren in the Netherlands: Comparing the effects of an online educational video game versus a leaflet or no intervention. BMC Public Health, 16(1), 1-10. https://doi.org/10.1186/s12889016-3811-5

Bond, K. T., \& Ramos, S. R. (2019). Utilization of an animated electronic health video to increase knowledge of post- A nd pre-exposure prophylaxis for HIV among African American Women: Nationwide cross-sectional survey. JMIR Formative Research, 3(2), 1-14. https://doi.org/10.2196/formative.9 995

Brame, C. J. (2016). Effective Educational Videos: Principles and Guidelines for Maximizing Student Learning from Video Content. CBE Life Sci Educ, 15(4). https://doi.org/doi: 10.1187/cbe.16-03-0125.

Cleeren, G., Quirynen, M., Ozcelik, O., \& Teughels, W. (2014). Role of 3D animation in periodontal patient education: A randomized controlled trial. Journal of Clinical Periodontology, 41(1), 38-45. https://doi.org/10.1111/jcpe.12170

Cynthia Ayu Ramadhanti, Dea Amarilisa
Adespin, H. P. J. (2019). PERBANDINGAN PENGGUNAAN METODE PENYULUHAN DENGAN DAN TANPA MEDIA LEAFLET TERHADAP PENGETAHUAN DAN SIKAP IBU TENTANG TUMBUH KEMBANG BALITA. Diponegoro Medical Journal, 8(1), 99-120.

Daniel Hogan, Tina DiMartino, Jianfang Liu , Kari A Mastro , Elaine Larson, E. C. (2018). Video-based Education to Reduce Distress and Improve Understanding among Pediatric MRI Patients: A Randomized Controlled Study. J Pediatr Nurs, 5963(17). https://doi.org/doi: 10.1016/j.pedn.2018.01.005

Govender, R., Taylor, S. A., Smith, C. H., \& Gardner, B. (2019). Helping patients with head and neck cancer understand dysphagia: Exploring the use of video-animation. American Journal of Speech-Language Pathology, 28(2), 697-705. https://doi.org/10.1044/2018_AJSL P-18-0184

Hardan-Khalil, K. (2020). Factors Affecting Health-Promoting Lifestyle Behaviors Among Arab American Women. Journal of Transcultural Nursing, 31(3), 267-275. https://doi.org/10.1177/104365961 9859056

Herron, E. K., Powers, K., Mullen, L., \& Burkhart, B. (2019). Effect of case study versus video simulation on nursing students' satisfaction, selfconfidence, and knowledge: A quasiexperimental study. Nurse Education Today, 79(March), 129-134. https://doi.org/10.1016/j.nedt.2019 .05 .015

Housten, A. J., Kamath, G. R., Bevers, T. B., Cantor, S. B., Dixon, N., Hite, A., Kallen, 
M. A., Leal, V. B., Li, L., \& Volk, R. J. (2020). Does Animation Improve Comprehension of Risk Information in Patients with Low Health Literacy? A Randomized Trial. Medical Decision Making, 40(1), 17-28. https://doi.org/10.1177/0272989X1 9890296

Hui Zhang, Evalotte Mörelius, Sam Hong Li Goh, W. W. (2019). Effectiveness of Video-Assisted Debriefing in Simulation-Based Health Professions Education: A Systematic Review of Quantitative Evidence. Nurse Education, 44(3), 1-6. https://doi.org/doi: 10.1097/NNE.0000000000000562

Joyce Mazza Nunes Aragão 1, Fabiane do Amaral Gubert 2, Raimundo Augusto Martins Torres 2, Andréa Soares Rocha da Silva 3, N. F. C. V. 1. (2018). The use of Facebook in health education: perceptions of adolescent students. Rev Bras Enferm, 71(2), 265-271. $\quad$ https://doi.org/doi: 10.1590/0034-7167-2016-0604.

Kayler, L. K., Keller, M. M., CrenesseCozien, N., Dolph, B., Cadzow, R., \& Feeley, T. H. (2019). Development and preliminary evaluation of ilearnKAS: An animated video about kidney allocation to support transplant decision-making. Clinical Transplantation, 33(8). https://doi.org/10.1111/ctr.13638

Li, J., Davies, M., Ye, M., Li, Y., Huang, L., \& Li, L. (2019). Impact of an Animation Education Program on Promoting Compliance With Active Respiratory Rehabilitation in Postsurgical Lung Cancer Patients. Cancer Nursing, Publish $\quad A h(0), \quad 1-10$. https://doi.org/10.1097/ncc.000000 0000000758
Mary Carter Denny, Farhaan Vahidy, Kim Y T Vu, Anjail Z Sharrief, S. I. S. (2017). Video-based educational intervention associated with improved stroke literacy, self-efficacy, and patient satisfaction. PLoS ONE, 12(3). https://doi.org/doi:

10.1371/journal.pone.0171952.

Melissa Goad, Huntley-Dale, R. W. (2018). The Use of Audiovisual Aids for Patient Education in the Interventional Radiology Ambulatory Setting: A Literature Review. Journal of Radiology Nursing, 37(3), 198-201. https://doi.org/10.1016/j.jradnu.20 18.06.003

Michelle O'Reilly, Nisha Dogra , Jason Hughes, Paul Reilly, Riya George, N. W. (2019). Potential of social media in promoting mental health in adolescents. Health Promot Int, 34(5), 981-991. https://doi.org/doi: 10.1093/heapro/day056

Ming-Huei Lee , Huei-Ching $\mathrm{Wu}$, ChienMing Tseng, Tsung-Liang Ko , TangJun Weng, Y.-F. C. (2018). Health Education and Symptom Flare Management Using a Video-based mHealth System for Caring Women With IC/BPS. Urology, 62-69. https://doi.org/doi: 10.1016/j.urology

Moher, D., Liberati, A., Tetzlaff, J., Altman, D. G., Altman, D., Antes, G., Atkins, D., Barbour, V., Barrowman, N., Berlin, J. A., Clark, J., Clarke, M., Cook, D., D’Amico, R., Deeks, J. J., Devereaux, P. J., Dickersin, K., Egger, M., Ernst, E., ... Tugwell, P. (2009). Preferred reporting items for systematic reviews and meta-analyses: The PRISMA statement. PLoS Medicine, 6(7).

https://doi.org/10.1371/journal.pm ed.1000097 
Muhson, A. (2010). Pengembangan Media Pembelajaran Berbasis Teknologi Informasi. Jurnal Pendidikan Akuntansi Indonesia, 8(2). https://doi.org/10.21831/jpai.v8i2.9 49

Nicola Rosaasen, Rahul Mainra, Azaad Kukha-Bryson, Victoria Nhin , Paraag Trivedi , Ahmed Shoker, Jay Wilson, Raj Padmanabh, H. M. (2018). Development of a patient-centered video series to improve education before kidney transplantation. Patient Educ Couns, 1624-1629(9), 1612-. https://doi.org/doi: 10.1016/j.pec.2018.04.014.

Nindya Kurniawati. (2012). Perbedaan Media Leaflet dan Video Terhadap Pengetahuan Ibu Tentang Cara Mengatasi Keluhan Pada Masa Kehamilan. In UNS-F. Kedokteran Program Diploma IV Bidan Pendidik.

Notoadmojo. (2011). Kesehatan Masyarakat Ilmu dan Seni. Rineka Cipta.

Notoatmodjo, S. (2010). Promosi Kesehatan: Teori dan Aplikasi. PT Rineka Cipta.

Oh, J. (2020). Factors A ff ecting HealthPromoting Behaviors among Nursing Students.

Pribadi, B. A. (2014). Desain dan Pengembangan Program Pelatihan Berbasis Kompetensi. Prenada Media Group.

Saengow, V. E., Chancharoenchai, P., Saartying, W., Pimpa, W., Chotichanon, N., Lewsirirat, T., \& Srisantisuk, P. (2018). Epilepsy video animation: Impact on knowledge and drug adherence in pediatric epilepsy patients and caregivers. Clinical
Neurology and Neurosurgery, 172(March), 59-61. https://doi.org/10.1016/j.clineuro.2 018.06.031

Sanjai Sinha, John Dillon, Savira Kochhar Dargar, Alexi Archambault, Paul Martin , Brittney A Frankel , Jennifer Inhae Lee , Amanda S Carmel, M. S., \& Expand, A. (2019). What to expect that you're not expecting: A pilot video education intervention to improve patient self-efficacy surrounding discharge medication barriers. Health Informatics J, 25(4), 1595-1605. https://doi.org/. doi: $10.1177 / 1460458218796644$

Sari, P. (2019). Analisis terhadap kerucut pengalaman Edgar Dale dan keragaman gaya belajar untuk memilih media yang tepat dalam pembelajaran. Mudir: Jurnal Manajemen Pendidikan, I(1), 58-78.

Stephanie N Pilieci, Saad Y Salim, Daithi S Heffernan, Kamal M F Itani, R. G. K. (2018). A Randomized Controlled Trial of Video Education versus Skill Demonstration: Which Is More Effective in Teaching Sterile Surgical Technique? Surg Infect (Larchmt), 19(3), 303-312. https://doi.org/doi: 10.1089/sur.2017.231.

Szeszak, S., Man, R., Love, A., Langmack, G., Wharrad, H., \& Dineen, R. A. (2016). Animated educational video to prepare children for MRI without sedation: evaluation of the appeal and value. Pediatric Radiology, 46(12), 1744-1750.

https://doi.org/10.1007/s00247-

016-3661-4

Thomas Brockfeld , Bringfried Müller, J. de L. (2018). Video versus live lecture courses: a comparative evaluation of lecture types and results. Med Educ 
Online, 23(1). https://doi.org/doi: 10.1080/10872981.2018.1555434

Wischer, J. L., Oermann, M. H., Zadvinskis, I. M., \& Kinney, K. C. (2018). Effects of iPad Video Education on Patient Knowledge, Satisfaction, and Cardiac Rehabilitation Attendance. Quality Management in Health Care, 27(4), 204-208.

https://doi.org/10.1097/QMH.0000

000000000185
Wouters, T., Soomers, J., Smink, M., Smit, R. A., Plaisier, M., Houterman, S., Bekkers, R. L., Schiffer, A. A., Pop, V. J., \& Piek, J. M. J. (2019). The effect of an animation video on consultation time, anxiety and satisfaction in women with abnormal cervical cytology: Animation video reduces colposcopy time. Preventive Medicine Reports, 13(July 2018), 238-243. https://doi.org/10.1016/j.pmedr.20 19.01.005 